Check for updates

Cite this: RSC Adv., 2019, 9, 29711

Received 30th July 2019

Accepted 15th September 2019

DOI: $10.1039 / c 9 r a 05900 h$

rsc.li/rsc-advances

\section{Novel camphor-based pyrimidine derivatives induced cancer cell death through a ROS-mediated mitochondrial apoptosis pathway $\dagger$}

\author{
Yan Zhang, ${ }^{a}$ Yunyun Wang, ${ }^{a}$ Yuxun Zhao, ${ }^{a}$ Wen Gu, (D) ac Yongqiang Zhu*b \\ and Shifa Wang (iD *ac
}

A series of novel camphor-based pyrimidine derivatives $(3 a-3 x)$ have been synthesized; their structures were determined by using conventional methods and compound $3 f$ was further confirmed through single crystal XRD analysis. The cytotoxic activity of the target compounds against a panel of human normal (GES-1) and cancer cell lines (MDA-MB-231, RPMI-8226, A549) was evaluated by MTS assay. Here we found that compound $3 f$ exhibited the strongest anti-tumor activity, comparable to that of etoposide, and had much lower cytotoxicity to normal GES-1 cells $\left(\mathrm{IC}_{50}>50 \mu \mathrm{M}\right)$ than the reference drug $\left(\mathrm{IC}_{50}=8.89 \mu \mathrm{M}\right)$. Subsequent mechanism studies in MDA-MB-231 cells revealed that compound $3 \mathrm{f}$ caused G0/G1 phase arrest and apoptosis in a dose dependent manner. Moreover, the loss of mitochondrial membrane potential and enhancement of cellular ROS levels were also observed upon $3 f$ treatment, which indicated that $3 f$ exerted cytotoxic activity by a ROS-mediated mitochondrial apoptosis pathway. This result was confirmed by a significant increase in the expression of pro-apoptotic proteins Bax, cytochrome $\mathrm{C}$ and caspase-3, and downregulation of anti-apoptosis protein Bcl-2. Overall, $3 f$ can be adopted for further investigation in the development of antitumor agents based on natural products.

\section{Introduction}

Cancer is one of leading causes of death globally. According to the statistics released by the World Health Organization (WHO), millions of new cancer patients are diagnosed each year worldwide. ${ }^{1}$ Although there has been steady progress made in reducing the mortality of cancer, the successful treatment of cancer remains a challenge. Mostly, therapeutic effectiveness of anti-cancer drugs is encumbered by some adverse side effects including high toxicity and drug resistance. Therefore, it is urgent to search for effective and safe agents for cancer treatment.

Recently, it has become increasingly evident that cancer therapy is mainly realized through the induction of apoptosis. ${ }^{2-4}$ Hence, developing reliable anticancer drugs, which can successfully induce apoptosis, has become the new focus of anti-tumor research. It's well-known that there are two major semi-interdependent pathways contributing to apoptosis: the

${ }^{a}$ College of Chemical Engineering, Nanjing Forestry University, Nanjing, Jiangsu 210037, People's Republic of China. E-mail: wangshifa65@163.com; Fax: +86 25 85427812; Tel: +862585427812

${ }^{b}$ Jiangsu Chia Tai Fenghai Pharmaceutical Co. Ltd, Nanjing, 210046, P. R. China

${ }^{c}$ Co-Innovation Center of Efficient Processing and Utilization of Forest Resources, Nanjing Forestry University, Nanjing, 210037, P. R. China

$\dagger$ Electronic supplementary information (ESI) available. CCDC 1838718. For ESI and crystallographic data in CIF or other electronic format see DOI: 10.1039/c9ra05900h death receptor pathway and the mitochondria apoptotic pathway. ${ }^{5}$ In the latter case, an early trigger of the apoptotic pathway is an increase in the permeability of the mitochondria membrane which is defined as sudden loss of the membrane potential $\left(\Delta \Psi_{\mathrm{m}}\right)$, causing release of apoptogenic factors including cytochrome C. ${ }^{6}$ Under normal circumstances, cytochrome $\mathrm{C}$ is bound to the cardiolipin from inner mitochondria membrane, which is susceptible to reactive oxygen species (ROS). ${ }^{7}$ Thus, the level of ROS could affect the dissociation of cytochrome $\mathrm{C}$ from the mitochondrial membrane, and further mediate the mitochondria apoptosis. Additionally, the release of cytochrome $\mathrm{C}$ is controlled by the expression of $\mathrm{Bcl}-2$ family proteins that contains pro-apoptotic proteins (Bcl-2, Bcl-xL, etc.) and anti-apoptotic proteins (Bax, Bak, etc.). ${ }^{8}$ Upon entering into the cytosol from mitochondria, cytochrome $\mathrm{C}$ would activate a cascade of caspases - a family of killer proteases, and eventually, result in cell death. ${ }^{9}$

The majority of the commercially available drugs are built on heterocyclic scaffolds and these chemical fragments are responsible for desired pharmacological activity. ${ }^{10}$ Pyrimidine, a six membered heterocyclic ring with nitrogen atom, exhibits various pharmacological activities such as anticancer, ${ }^{\mathbf{1 1 - 1 3}}$ antimicrobial, ${ }^{14,15}$ antiviral, ${ }^{16-18}$ anti-tubercular, ${ }^{19,20}$ anti-inflammatory, ${ }^{21,22}$ antimalarial, ${ }^{23,24}$ anti-diabetic ${ }^{25}$ and antipyretic. ${ }^{26}$ Among these diverse pyrimidine derivatives, amino-pyrimidine plays a vital role in the therapeutic activities against cancers, meanwhile, a large number of studies have been reported in 
recent years. ${ }^{27-30}$ Natural compounds are the most promising source for the synthesis of biologically active substances in medicinal chemistry. Camphor, as one of the important monoterpenoids, is widespread in plants and has been used as chiral, enantiopure starting materials. ${ }^{31-33}$ Moreover, camphorbased derivatives exhibit a number of biological activities. For instance, $\mathrm{N}$-arylpiperazine camphor sulfonamides were discovered as novel CXCR3 antagonists, ${ }^{34}$ camphor-based cyanopyrrolidines were used as inhibitors for the treatment of type 2 diabetes mellitus, ${ }^{35}$ the camphane-based amides presented the promising anti-mycobacterial activity. ${ }^{36}$ Aliphatic and alicyclic camphor imines showed significant activity against influenza virus $\mathrm{H} 1 \mathrm{~N} 1,{ }^{37}$ the platinum(II) complex possessing camphoryl had antiproliferative activity. ${ }^{38}$ From the view of the chemical structure, camphor is a small molecule with chirality and rigidity property which may bind to some active site, together with its low cost and convenience to transform into synthetically useful derivatives, it can serve as a good building block of bioactive leading compounds.

In view of the above-mentioned facts, it was envisaged that combining these two pharmacological scaffolds would construct novel molecular templates which are likely to show interesting biological properties. Based on the previous studies of anticancer drug in our research team, in this study, we coupled amino-pyrimidine fragments to camphor scaffold by a cyclization reaction to synthesize 24 novel camphor-based pyrimidine derivatives. Besides, we evaluated the cytotoxic activities of the target compounds by MTS in three different human-derived cancer cell lines including breast cancer cells (MDA-MB-231), multiple myeloma cells (RPMI-8226) and nonsmall cell lung cancer cells (A549), and explored the possible preliminary mechanism of the most potent compound $3 \mathbf{f}$ in MDA-MB-231 cells.

\section{Results and discussion}

\subsection{Synthesis and characterization}

With commercially available camphor 1 as the starting material, a series of pyrimidine derivatives were synthesized via two simple steps, following the route outlined in Scheme 1. Initially, aldol condensation of the compound $\mathbf{1}$ with various substituted aromatic aldehydes was carried out to prepare intermediates 2a-2x. Subsequently, without purification, intermediates $\mathbf{2 a - 2 x}$

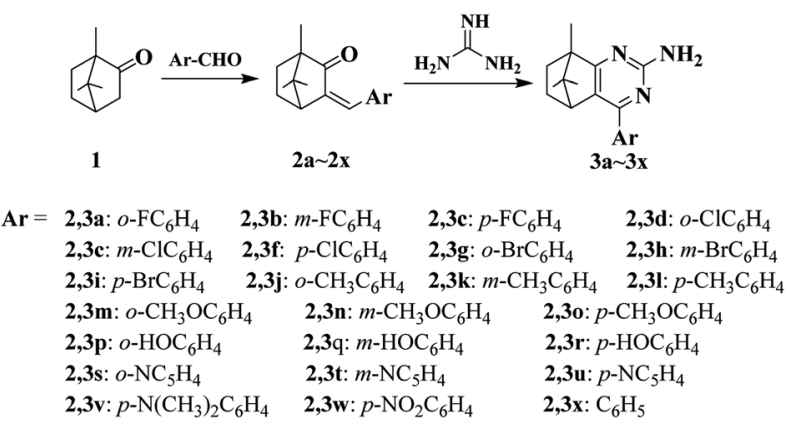

Scheme 1 Synthesis of compounds $3 a-3 x$. reacted respectively with guanidine hydrochloride under basecatalyzed cyclization conditions to obtain target compounds 3a-3x in excellent yields. All desired pyrimidine analogs were purified by recrystallization and characterized by ${ }^{1} \mathrm{H}$ NMR, ${ }^{13} \mathrm{C}$ NMR and HRMS analysis. As exemplified with the ${ }^{1} \mathrm{H}$ NMR analysis of 4-(4-chlorophenyl)-8,9,9-trimethyl-5,6,7,8tetrahydro-5,8-methanoquinazolin-2-amine $\quad(3 \mathbf{3 f}),{ }^{1} \mathrm{H} \quad \mathrm{NMR}$ spectra revealed appearance of $\mathrm{NH}_{2}$ signal at $\delta 5.27 \mathrm{ppm}$, meanwhile, two symmetric doublets at $\delta$ 7.41-7.73 ppm were corresponding to aromatic protons. The ${ }^{13} \mathrm{C}$ NMR spectrum of 3f displayed all characteristic peaks corresponding to molecular structure. For the pyrimidine ring, three aromatic carbons adjacent to $\mathrm{N}$ atom at $\delta 182.11,161.75$ and $154.87 \mathrm{ppm}$ were found, respectively. The presence of two high peaks at $\delta 128.67$ and $129.63 \mathrm{ppm}$ confirmed the para-substituted structure of $p$ chlorophenyl moiety. Besides, some representative spectra are given in ESI. $\dagger$

\subsection{Crystal structure of the compound $3 f$}

The single crystal of $\mathbf{3 f}$ was grown from chloroform solvent by the slow evaporation at room temperature. The compound $\mathbf{3 f}$ belongs to triclinic system with space group $P \overline{1}, a=6.9895(2) \AA$, $b=8.6676(3) \AA, c=13.6291(5) \AA, \alpha=76.606(2)^{\circ}, \beta=81.336(2)^{\circ}$, $\gamma=79.948(2)^{\circ}, Z=2, \mathrm{~V}=785.64(5) \AA^{3}$. Molecular structure of compounds $3 \mathrm{f}$ together with the atom labeling scheme is given in Fig. 1, and the crystal data and structure refinement details are summarized in Table S1. $\dagger$ Crystallographic data of the compound 3f was deposited with the Cambridge Crystallographic Data Centre (CCDC) No 1838718.

\subsection{Biological evaluation of compounds assay}

All target compounds were appraised for the anticancer activities against three human malignant cell lines (lung adenocarcinoma A549, breast cancer MDA-MB-231, multiple myeloma RPMI-8226) by using MTS assay. The preliminary screening results were presented graphically in Fig. 2.

As depicted in Fig. 2, it is noticeable that most of compounds displayed little cytotoxic effect against all tested cancer cell lines at testing concentrations ( $50 \mu \mathrm{M}$ and $10 \mu \mathrm{M})$, in contrast, only several compounds showed strong growth inhibition (above $50 \%$ inhibition). Interestingly, for RPMI-8226 cell line, there is no obvious difference in the growth inhibition with the decrease of testing concentration from $50 \mu \mathrm{M}$ to $10 \mu \mathrm{M}$, but this trend

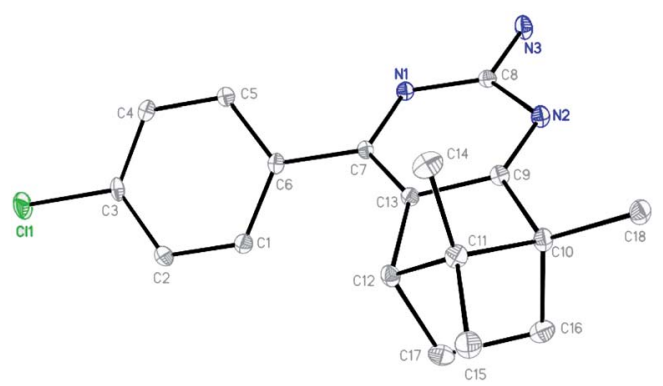

Fig. 1 X-ray crystal structure of compound $3 f$. 

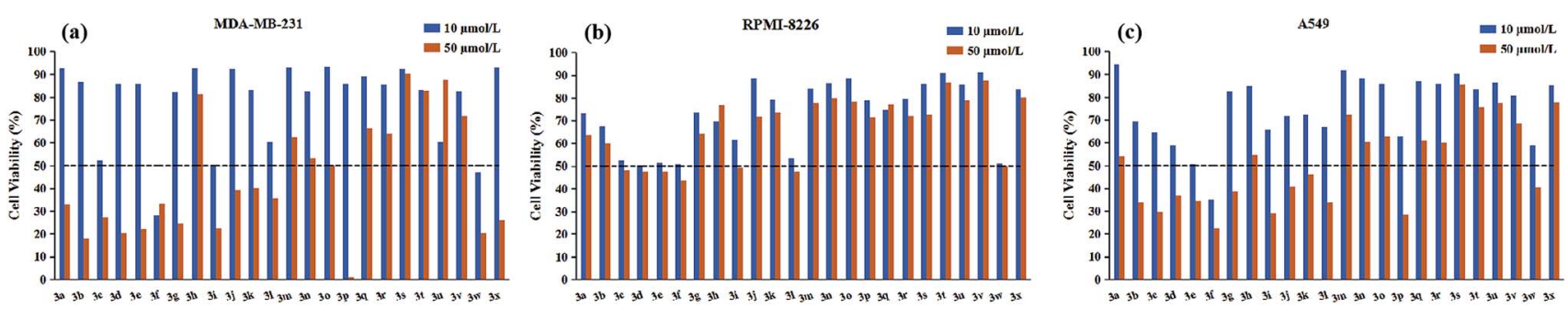

Fig. 2 The cell viability of synthesized compounds against (a) MDA-MB-231 (b) RPMI-8226 (c) A549 cancer cell line at testing concentrations of $10 \mu \mathrm{M}$ and $50 \mu \mathrm{M}$. The dashed line across the graph represents the threshold percentage for further $\mathrm{IC}_{50}$ determination. Cell viability was measured by MTS assay.

was not observed in the other two cell lines. On the other hand, considering the inhibitory selectivity of designed compounds on selected cancer cell lines, these pyrimidine derivatives present a preferable MDA-MB-231 targeting structure because the majority of tested analogs showed higher MDA-MB-231 inhibition compared with their respective activity on the other two cancer cell lines. In order to gain better insight into the role of different structural functionalities on cytotoxic effect, $\mathrm{IC}_{50}$ determination study was performed in triplicate and the results of the mean values were summarized in Table 1 , in which etoposide was used as a positive control.

As illustrated with Table 1, the majority of compounds (3a3i) with halogen group showed improved inhibitory activity, especially, of which compound $\mathbf{3 f}$ bearing chlorine atom was identified as the most promising candidates due to their lowest overall $\mathrm{IC}_{50}$ values (ranging from 5.00 to $8.64 \mu \mathrm{M}$ ) comparable to etoposide. Meanwhile, introduction of nitro group on the phenyl ring (3w) also resulted in good cytotoxicity with $\mathrm{IC}_{50}$ values similar to compound $\mathbf{3 f}$. However, the substituents $(\mathbf{3} \mathbf{j}-\mathbf{3 r}$ and $3 \mathbf{v}$ ) with the electron-donating group showed decreased or complete loss of activity. Besides, the replacement of phenyl ring with pyridine ring $(3 \mathbf{s}-3 \mathbf{u})$ also largely weakened the activity against three cancer cell lines. These results indicated that the electron deficiency of the phenyl ring is a favorable feature to increase anticancer potential. In addition to substituting functional group, substitution position was also found to play a role in altering the cytotoxicity of synthesized compounds. Close observation of results from Table 1, para-substitution of phenyl ring (3c, 3f, 3i, 3l) exerted the most potent activity compared to their respective ortho- and meta-substituted analogs regardless

Table 1 Antiproliferative activities of compounds $3 a-3 x$

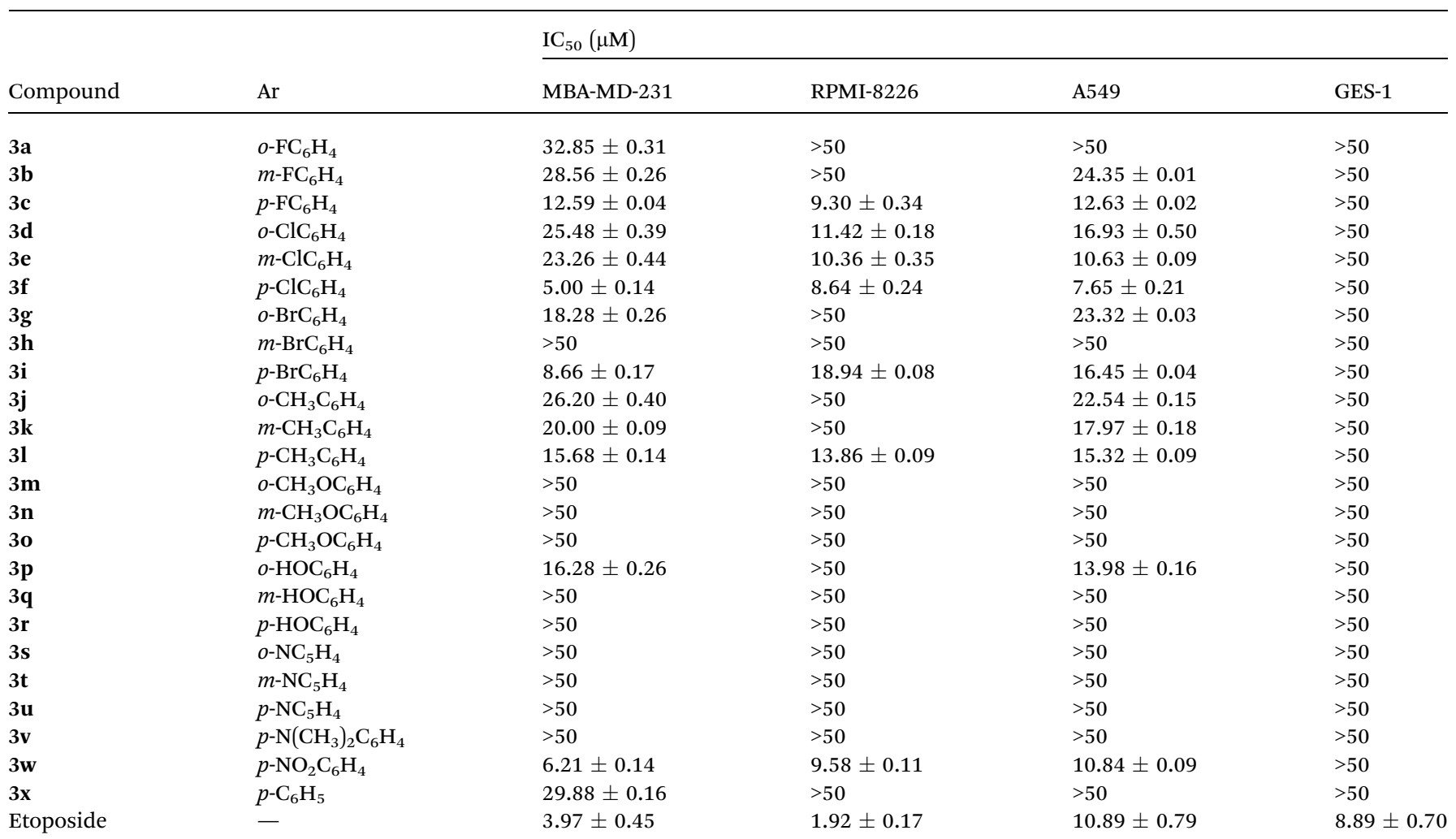


to the substituting functional groups, except $\mathbf{3 p}$ which dramatically increased the potency in two solid tumor cell lines (A549 and MDA-MB-231). On top of this, meta-substituted derivatives $(\mathbf{3} \mathbf{b}, \mathbf{3 e}, \mathbf{3 k})$ performed better in reducing cancer cells viability than that of ortho-substitutions (3a, 3d, 3j), but the trend was reversed when only meta-brominated compound 3h was being considered. According to above findings, we can conclude that the tested pyrimidine derivatives with phenyl ring bearing electron withdrawing group at $p$-position have a positive influence on antitumor activity. Furthermore, all compounds were examined for possible toxicity against GES-1 (normal human gastric epithelial cell line). We found that none of compounds showed significant toxicity toward GES-1, whereas the reference compound (etoposide) exhibited severe cytotoxicity $\left(\mathrm{IC}_{50}=8.89 \mu \mathrm{M}\right)$.

\subsection{Cell cycle assay}

The cytotoxicity results, which were discussed earlier, suggest $\mathbf{3 f}$ is the most potent compound, especially in MDA-MB-231 cells. The perturbation of cell cycle is closely associated to the cytotoxicity, to determine whether $3 \mathbf{f}$ might trigger the arrest of cell cycle, a flow-cytometric analysis of MDA-MB-231 cells stained with propidium iodide (PI) was conducted. After the cells were treated with various concentrations of $3 \mathrm{f}(2.5,5$ and $10 \mu \mathrm{M})$ for $72 \mathrm{~h}$, significant alternations in the cell phases were observed. In Fig. 3, compared with $56.86 \%$ in the control, the percentage of cells in the G0/G1 phase after treatment with $2.5,5,10 \mu \mathrm{M}$ of compound 3f steadily increased to $64.89 \%, 78.02 \%$, and $81.72 \%$, accompanied by decreasing the proportion of cells at G2/M and S phase of cell cycle. Therefore, these results illustrated that 3f induced an obvious G0/G1 arrest in a concentration-dependent manner.

\subsection{Apoptosis analysis}

To get further insight into the mechanism of cell death induced by compound $\mathbf{3 f}$, apoptosis in treated MDA-MB-231 cells was

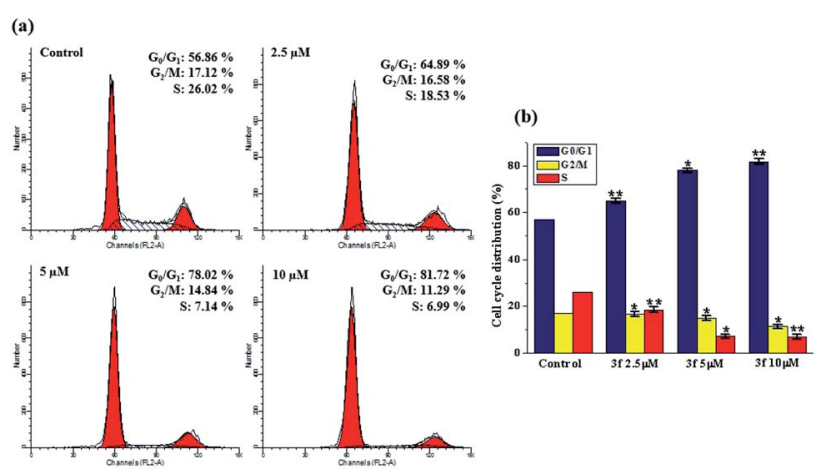

Fig. 3 Influence of compound $3 f$ on cell cycle distribution in MDAMB-231 cells. (a) Cells were treated with different concentrations (2.5, 5 and $10 \mu \mathrm{M}$ ) of compound $3 \mathrm{f}$ for $72 \mathrm{~h}$, which then were stained with propidium iodide (PI), and the DNA content were analyzed by flow cytometry. (b) Percentages of cells in various phases of the cell cycle. These data are from three independent experiments. ${ }^{*} p<0.05$; ${ }^{* *} p<$ 0.01 , verse the negative control. quantified by the Annexin V-APC/7-AAD double staining flow cytometric assay, in which Annexin V may specifically bind to the early apoptosis marker phosphatidylserine (PS) exposed on the outside of the cell (green fluorescence) and 7-AAD (7-aminoactinomycin D) can stain DNA and enter only dead and late apoptotic cells (red fluorescence). As shown in dot plot (Fig. 4), a high percentage of the control (untreated) MDA-MB-231 cells were negative for both Annexin V and 7-AAD (97.4\%). After the completion of $72 \mathrm{~h}$ incubation with $2.5 \mu \mathrm{M}$ compound $3 \mathbf{f}$, a little amount of cell lines (3.78\%) were in early stage of the apoptosis, and $5.69 \%$ of cancer cells were appeared in late apoptosis. A similar pattern was observed in MDA-MB-231 cells treated with $5 \mu \mathrm{M}$ of compound $3 \mathbf{f}$ as well. Exposure of MDA-MB-231 cells to $10 \mu \mathrm{M}$ of $\mathbf{3 f}$ resulted in significant increase in percentage of late apoptotic cells by $38.4 \%$, in contrast, caused no changes in the levels of early apoptotic cells. In a word, the total (early and late) ratios of apoptosis enhanced from $9.47 \%$ to $57.9 \%$, indicating that anti-proliferative effect of $\mathbf{3 f}$ depended on apoptosis.

\subsection{Intracellular ROS level}

Reactive oxygen species (ROS) are recognized as a pivotal factor in intracellular signaling and regulation. Cell growth and proliferation are encouraged with a condition of a modest rise in intracellular ROS, on the other hand, the elevation of ROS is consequent to disruption of intracellular redox homeostasis and inhibition of biomacromolecules function, resulting in promoting cell death. Since cancer cells are more sensitive to enhanced intracellular ROS than the nontransformed cells, the regulation of intracellular ROS levels could be exploited for selective therapeutic approach of cancer. To determine whether the anticancer effect of active compound $\mathbf{3 f}$ is involved in ROSmediated therapy, the level of ROS in MDA-MB-231 cells treated with compound $3 \mathrm{f}$ at $10 \mu \mathrm{M}$ concentration increased by almost 12 times $(63.4 \%)$ in comparison to the control group $(5.13 \%)$ (Fig. 5). However, the promoted intracellular ROS accumulation induced by $3 \mathbf{f}$ was distinctly suppressed by $\mathrm{N}$-acetyl cysteine (NAC), which is one of the ROS scavengers. On the basis of these results, it clearly indicated that compound $3 \mathbf{f}$ can modulate the

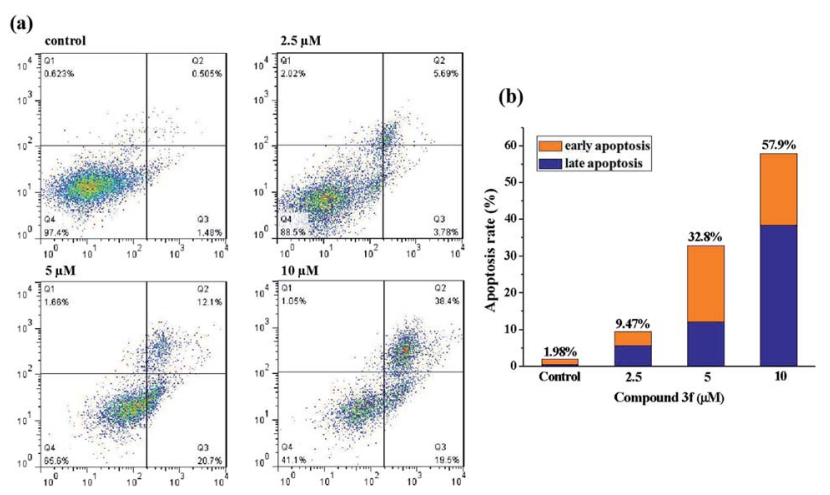

Fig. 4 Compound $3 f$ induced apoptosis in MDA-MB-231 cells. (a) Flow cytometry analysis of MDA-MB-231 cells were treated with compound $3 f(2.5,5$ and $10 \mu \mathrm{M})$ for $72 \mathrm{~h}$, respectively, and stained with Annexin V-APC/7-AAD. (b) Quantitative analysis of apoptotic cells in histogram. These data are from three independent experiments. 
(a)

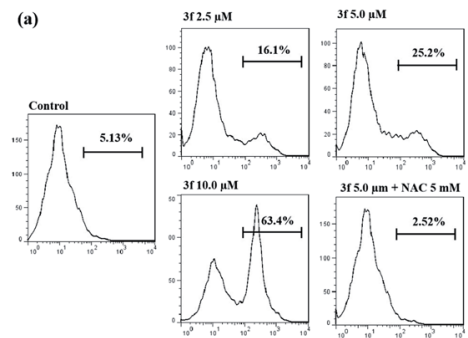

Fig. 5 Effect of compound $3 f$ on ROS production. (a) Analysis of the ROS levels by flow cytometry after the MDA-MB-231 cells were treated with compound $3 f$ at indicated concentrations or in presence of NAC for $72 \mathrm{~h}$ and stained with DCFH-DA. (b) Quantification of the flow cytometric results. These data are from three independent experiments. ${ }^{*} p<0.05$ verse the negative control.

generation of intracellular ROS, and at least partly, explain the anticancer activity of compound $\mathbf{3 f}$.

\subsection{Mitochondrial membrane potential (MMP) analysis}

It's well-known that there are two major semi-interdependent routes contributing to apoptosis. One is initiated by ligand binding to the death receptors at the cell surface (extrinsic apoptotic pathway), the other involves mitochondria (intrinsic apoptotic pathway). In the latter case, an early trigger of the apoptotic pathway is an increase in the permeability of the outer membrane, which leads to a preliminary reduction of the mitochondrial membrane potential $\left(\Delta \Psi_{\mathrm{m}}\right)$. Hence, in order to understand the mechanism of apoptosis, we used JC-1 as a fluorescent probe, a liquid crystal-forming cationic dye which can reversibly change its color from red to green as membrane potential decreases, to observe the effect of compound $\mathbf{3 f}$ on $\Delta \Psi_{\mathrm{m}}$. The results are presented in Fig. 6, in the control, the percentage of green fluorescent cells is 3.9\%, whereas MDA-MB231 cells were exposed to $3 \mathbf{f}$ at different concentration $(2.5 \mu \mathrm{M}, 5$ $\mu \mathrm{M}$ and $10 \mu \mathrm{M}$ ) for $72 \mathrm{~h}$, there is a gradual increase of the

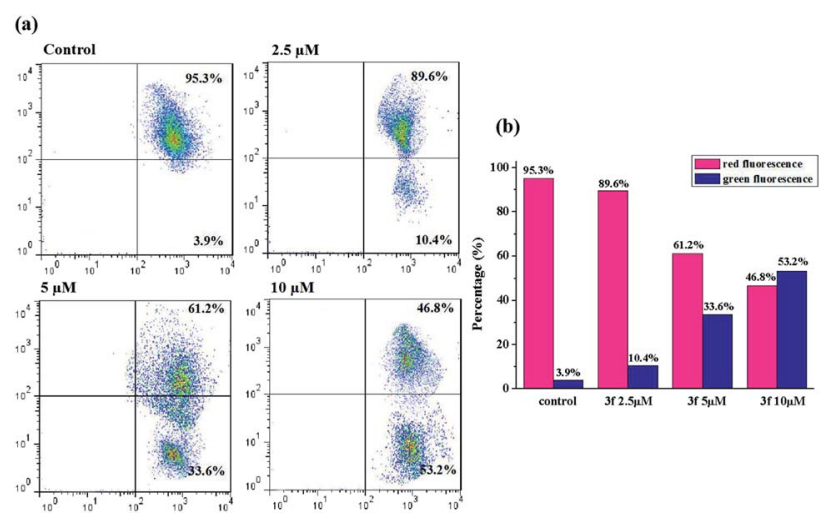

Fig. 6 Determination of mitochondrial membrane potential in MDAMB-231 cells. (a) Cells were treated with compound $3 f(2.5,5$ and 10 $\mu \mathrm{M})$ for $72 \mathrm{~h}$ and observed the changes in mitochondrial membrane potential by flow cytometry. (b) Bar graph represents the percentage distribution of cells with red fluorescence or green fluorescence. These data are from three independent experiments. percentage of cells with a collapsed $\Delta \Psi_{\mathrm{m}}$ (from $3.9 \%$ to $10.4 \%$, $33.6 \%, 53.2 \%$ ). Based on such study, we concluded that the compound $3 \mathrm{f}$ could mediate perturbation of the mitochondrial membrane integrity with a consequent concentrationdependent collapse of $\Delta \Psi_{\mathrm{m}}$, and its antiproliferative activities might be associated with mitochondrial apoptosis pathway.

\subsection{Western blot analysis}

Aforementioned findings indicated that compound $\mathbf{3 f}$ gave rise to a preliminary disruption of the mitochondrial transmembrane potential $\left(\Delta \Psi_{\mathrm{m}}\right)$, which would be the consequence of mitochondrial membrane permeabilization. This permeabilization is chiefly mediated and controlled by Bcl-2 family members which mainly includes pro-survival group (Bcl-2, Bcl$\mathrm{xL}$, etc.), pro-apoptotic group (Bax, Bak, etc.) and apoptosis initiator group (Bid, Bim, etc.). The ratio of anti- to proapoptotic molecules constitutes a rheostat that sets the threshold of susceptibility to apoptosis for the intrinsic pathway. In the presence of apoptotic stimuli, the expression of pro-apoptotic proteins increased and the release of pro-survival proteins is inhibited, which leads to cytochrome $\mathrm{C}$ release from the intermembrane space of mitochondria to the cytoplasm, likely by forming a channel in the outer mitochondrial membrane. The released cytochrome $\mathrm{C}$ binds to apoptosis protease-activating factor 1 (Apaf-1) and procaspase-9, generating apoptosome. Consecutively, the executioner caspase- 3 is recruited to the apoptosome, where it is activated by the resident caspase-9. Then, caspase- 3 cleaves key substrates in the cell to produce many of the cellular and biochemical events of apoptosis. In the present study, several apoptosis associated molecules, such as Bcl-2, Bax, cytochrome C, and caspase-3, were evaluated. After treatment with compound $3 \mathbf{f}(2.5 \mu \mathrm{M}, 5$ $\mu \mathrm{M}$ and $10 \mu \mathrm{M}$ ) for $72 \mathrm{~h}$, the levels of apoptosis inducing proteins in MDA-MB-231 cells were tested via western blot assays. As depicted in Fig. 7, the expression of anti-apoptosis protein Bcl-2 was downregulated dose-dependently, whereas the expression of pro-apoptotic proteins Bax was up-regulated. Besides, the upregulation of cytochrome $\mathrm{C}$ and caspase- 3 were

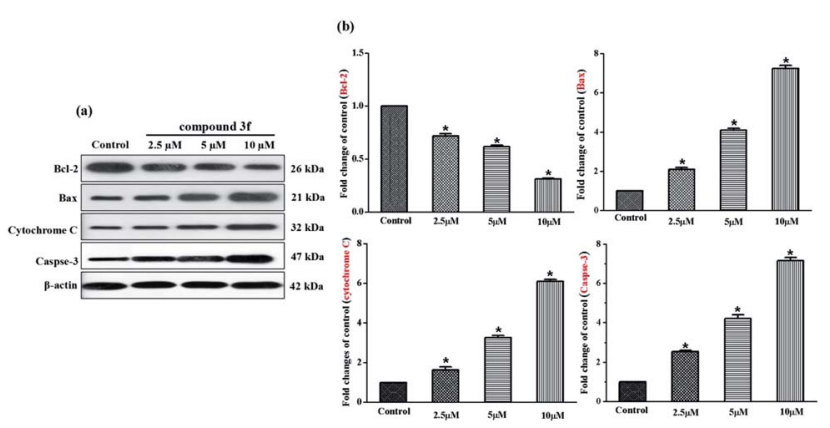

Fig. 7 Expression changes of apoptosis related proteins. (a) Western blot analysis of Bcl-2, Bax, cytochrome C, caspase-3 in MDA-MB-231 cells treated with compound $3 f(2.5,5$ and $10 \mu \mathrm{M})$ for $72 \mathrm{~h}, \beta$-actin was used as the internal reference. (b) Statistical analysis of protein expression levels. These data are from three independent experiments. $* p<0.05$ verse the negative control. 
also observed compared with the control. Thus, these results confirmed that compound $\mathbf{3 f}$ can induce mitochondria-related apoptosis.

\section{Experimental}

\subsection{Chemistry}

Starting materials and chemical reagents were purchased from Aladdin or Energy, and used without further purification. Solvents were purchased from common commercial suppliers. Thin-layer chromatography (TLC) was utilized to monitor the reaction progress, and components were visualized under $254 \mathrm{~nm}$ illumination. The purity of target compounds evaluated biologically was greater than $98 \%$ by America Agilent 1260 high performance liquid chromatography (HPLC) analysis. ${ }^{1} \mathrm{H}(400$ $\mathrm{MHz}$ ) and ${ }^{13} \mathrm{C}$ NMR (100 MHz) spectra were recorded on Bruker Advance spectrometer in $\mathrm{CDCl}_{3}$, DMSO- $d_{6}$ solutions. The proton and carbon chemical shifts (ppm) are given with respect to tetramethylsilane (TMS). High resolution mass spectra (HRMS) were obtained by using Agilent 6540 high-resolution mass spectrometer. Melting points were measured on OptimeltMPA100 melting point apparatus (uncorrected). X-ray diffraction analysis was determined on a Bruker D8 Venture area diffractometer.

3.1.1. Synthesis of compounds $2 \mathrm{a}-2 \mathrm{x}$. In a $50 \mathrm{ml}$ dried three-necked flask equipped with a stirrer, thermometer and condenser, camphor ( $8 \mathrm{mmol})$, aromatic aldehyde $(10 \mathrm{mmol})$, tert-butanol $(35 \mathrm{ml})$, and potassium tert-butoxide $(8 \mathrm{mmol})$ were added in sequence. The mixture was refluxed for 6-12 h until the conversion ratio of camphor exceeded $95 \%$ (monitored by TLC). After completion of reaction, the reaction mixture was evaporated under vacuum and extracted three times with $20 \mathrm{ml}$ ethyl acetate, then merged organic layers were washed, dried and evaporated to afford the concentrated solution. After adding a small amount of ethanol, the intermediates $\mathbf{2 a - 2 x}$ were precipitated out, and obtained by filtration.

3.1.2. Synthesis of target compounds 3a-3x. Guanidine hydrochloride ( $8 \mathrm{mmol})$, intermediates $2 \mathbf{a}-2 \mathbf{x}(2 \mathrm{mmol})$, potassium tert-butoxide (12 mmol) were dissolved in tert-butanol (35 $\mathrm{ml})$. The reaction mixture was refluxed for $24-48 \mathrm{~h}$ and monitored by TLC until the spot of $\mathbf{2 a - 2 x}$ in silica gel plate almost disappeared. After completion of reaction, the reaction mixture was evaporated under vacuum and extracted three times with $20 \mathrm{ml}$ ethyl acetate, then merged organic layers were washed, dried and concentrated. Finally, the crude product was recrystallized from methanol and filtered to give target compound 3a$3 \mathbf{x}$ (the purity was above $98 \%$ ).

3.1.2.1. 4-(2-Fluorophenyl)-8,9,9-trimethyl-5,6,7,8-tetrahydro5,8-methanoquinazolin-2-amine (3a). Yield 92\%; $\mathrm{mp} 166.2$ 166.4 ${ }^{\circ} \mathrm{C} .{ }^{1} \mathrm{H}$ NMR $\left(400 \mathrm{MHz}, \mathrm{CDCl}_{3}\right) \delta: 7.57(\mathrm{~s}, 1 \mathrm{H}), 7.40(\mathrm{~s}, 1 \mathrm{H})$, $7.13(\mathrm{~s}, 2 \mathrm{H}), 5.39(\mathrm{~s}, 2 \mathrm{H}), 2.79(\mathrm{~s}, 1 \mathrm{H}), 2.28(\mathrm{~s}, 1 \mathrm{H}), 2.18(\mathrm{~s}, 1 \mathrm{H})$, 1.90 (s, 1H), 1.32 (s, 1H), 1.25 (s, 3H), 0.97 (s, 3H), 0.66 (s, 3H); ${ }^{13} \mathrm{C}$ NMR $\left(100 \mathrm{MHz}, \mathrm{CDCl}_{3}\right) \delta: 181.40,161.89,158.46,151.97$, 131.02, 130.70, 127.79, 125.87, 124.34, 116.03, 56.00, 54.64, 49.55, 31.78, 25.77, 19.83, 18.97, 10.04; HR-MS $\left(\mathrm{ESI}^{+}\right): \mathrm{m} / \mathrm{z}$ calculated for $\mathrm{C}_{18} \mathrm{H}_{20} \mathrm{FN}_{3}[\mathrm{M}+\mathrm{H}]^{+}$298.1720, found 298.1717.
3.1.2.2. 4-(3-Fluorophenyl)-8,9,9-trimethyl-5,6,7,8-tetrahydro5,8-methanoquinazolin-2-amine (3b). Yield 88\%; $\mathrm{mp} 155.4-$ 155.9 ${ }^{\circ} \mathrm{C} .{ }^{1} \mathrm{H}$ NMR $\left(400 \mathrm{MHz}, \mathrm{CDCl}_{3}\right) \delta: 7.49-7.55$ (m, 2H), 7.39$7.44(\mathrm{~m}, 1 \mathrm{H}), 7.09-7.14(\mathrm{~m}, 1 \mathrm{H}), 5.31(\mathrm{~s}, 2 \mathrm{H}), 3.06(\mathrm{~d}, J=4 \mathrm{~Hz}$, $1 \mathrm{H}), 2.18-2.23(\mathrm{~m}, 1 \mathrm{H}), 1.86-1.96(\mathrm{~m}, 1 \mathrm{H}), 1.32-1.37(\mathrm{~m}, 2 \mathrm{H})$, $1.25(\mathrm{~s}, 3 \mathrm{H}), 0.99(\mathrm{~s}, 3 \mathrm{H}), 0.63(\mathrm{~s}, 3 \mathrm{H}) ;{ }^{13} \mathrm{C} \mathrm{NMR}\left(100 \mathrm{MHz}, \mathrm{CDCl}_{3}\right)$ $\delta: 182.24,164.11,161.75,154.70,140.38,129.98,125.48,123.96$, 116.18, 115.33, 55.96, 54.25, 49.65, 31.76, 25.95, 19.96, 18.98, 10.03; HR-MS $\left(\mathrm{ESI}^{+}\right): \mathrm{m} / z$ calculated for $\mathrm{C}_{18} \mathrm{H}_{20} \mathrm{FN}_{3}[\mathrm{M}+\mathrm{H}]^{+}$ 298.1720, found 298.1717 .

3.1.2.3. 4-(4-Fluorophenyl)-8,9,9-trimethyl-5,6,7,8-tetrahydro5,8-methanoquinazolin-2-amine (3c). Yield 91\%; mp 197.0197.9 ${ }^{\circ} \mathrm{C} .{ }^{1} \mathrm{H}$ NMR $\left(400 \mathrm{MHz}, \mathrm{CDCl}_{3}\right) \delta: 7.75-7.79(\mathrm{~m}, 2 \mathrm{H}), 7.14(\mathrm{t}$, $J=8 \mathrm{~Hz}, 2 \mathrm{H}), 5.27(\mathrm{~s}, 2 \mathrm{H}), 3.03(\mathrm{~d}, J=3.9 \mathrm{~Hz}, 1 \mathrm{H}), 2.16-2.22(\mathrm{~m}$, $1 \mathrm{H}), 1.86-1.95(\mathrm{~m}, 1 \mathrm{H}), 1.32-1.36(\mathrm{~m}, 2 \mathrm{H}), 1.25(\mathrm{~s}, 3 \mathrm{H}), 0.99(\mathrm{~s}$, $3 \mathrm{H}), 0.63(\mathrm{~s}, 3 \mathrm{H}) ;{ }^{13} \mathrm{C} \mathrm{NMR}\left(100 \mathrm{MHz}, \mathrm{CDCl}_{3}\right) \delta: 181.98,164.66$, $161.74,155.07,134.17,130.24,125.17,115.32$, 55.97, 54.21, 49.70, 31.76, 25.97, 19.95, 19.01, 10.03; HR-MS $\left(\mathrm{ESI}^{+}\right): \mathrm{m} / \mathrm{z}$ calculated for $\mathrm{C}_{18} \mathrm{H}_{20} \mathrm{FN}_{3}[\mathrm{M}+\mathrm{H}]^{+}$298.1720, found 298.1717.

3.1.2.4. 4-(2-Chlorophenyl)-8,9,9-trimethyl-5, 6,7,8-tetrahydro5,8-methanoquinazolin-2-amine (3d). Yield 92\%; $\mathrm{mp}$ 185.5$185.8{ }^{\circ} \mathrm{C} .{ }^{1} \mathrm{H}$ NMR $\left(400 \mathrm{MHz}, \mathrm{CDCl}_{3}\right) \delta: 7.45-7.48(\mathrm{~m}, 3 \mathrm{H}), 7.31-$ $7.36(\mathrm{~m}, 3 \mathrm{H}), 5.20(\mathrm{~s}, 2 \mathrm{H}), 2.69(\mathrm{~d}, J=4 \mathrm{~Hz}, 1 \mathrm{H}), 1.97-2.04(\mathrm{~m}$, $1 \mathrm{H}), 1.84-1.87$ (m, 1H), 1.30-1.33 (m, 1H), 1.27 (s, 3H), 1.14-1.20 (m, 1H), 0.97 (s, 3H), $0.74(\mathrm{~s}, 3 \mathrm{H}) ;{ }^{13} \mathrm{C} \mathrm{NMR}\left(100 \mathrm{MHz}, \mathrm{CDCl}_{3}\right) \delta$ : $181.27,161.59,155.60,137.18,132.15,130.30,129.82,129.73$, 127.53, 126.81, 56.14, 54.66, 48.82, 31.86, 25.87, 19.91, 18.93, 9.94; HR-MS $\left(\mathrm{ESI}^{+}\right): \mathrm{m} / z$ calculated for $\mathrm{C}_{18} \mathrm{H}_{20} \mathrm{ClN}_{3}[\mathrm{M}+\mathrm{H}]^{+}$ 314.1424, found 314.1420.

3.1.2.5. 4-(3-Chlorophenyl)-8,9,9-trimethyl-5, 6,7,8-tetrahydro5,8-methanoquinazolin-2-amine (3e). Yield 87\%; mp 162.8$163.2{ }^{\circ} \mathrm{C} .{ }^{1} \mathrm{H}$ NMR $\left(400 \mathrm{MHz}, \mathrm{CDCl}_{3}\right) \delta: 7.78(\mathrm{~s}, 1 \mathrm{H}), 7.61-7.64$ (m, 1H), 7.38-7.39 (m, 1H), 5.25 (s, 2H), 3.05 (d, $J=4 \mathrm{~Hz}, 1 \mathrm{H})$, 2.17-2.23 (m, 1H), 1.86-1.96 (m, 1H), 1.34 (t, $J=8 \mathrm{~Hz}, 2 \mathrm{H}), 1.25$ (s, 3H), 0.99 (s, 3H), 0.63 (s, 3H); ${ }^{13} \mathrm{C}$ NMR (100 MHz, $\left.\mathrm{CDCl}_{3}\right) \delta$ : 182.24, 161.73, 154.59, 139.87, 134.55, 129.66, 129.22, 128.39, 126.42, 125.56, 55.99, 54.25, 49.61, 31.73, 25.96, 19.96, 18.98, 10.02; HR-MS $\left(\mathrm{ESI}^{+}\right): \mathrm{m} / z$ calculated for $\mathrm{C}_{18} \mathrm{H}_{20} \mathrm{ClN}_{3}[\mathrm{M}+\mathrm{H}]^{+}$ 314.1424 , found 314.1423 .

3.1.2.6. 4-(4-Chlorophenyl)-8,9,9-trimethyl-5,6,7,8-tetrahydro5,8-methanoquinazolin-2-amine (3f). Yield 94\%; $\mathrm{mp}$ 192.3192.6 ${ }^{\circ} \mathrm{C} .{ }^{1} \mathrm{H}$ NMR $\left(400 \mathrm{MHz}, \mathrm{CDCl}_{3}\right) \delta: 7.71(\mathrm{~d}, J=12 \mathrm{~Hz}, 2 \mathrm{H})$, $7.42(\mathrm{~d}, J=12 \mathrm{~Hz}, 2 \mathrm{H}), 5.27(\mathrm{~s}, 2 \mathrm{H}), 3.0(\mathrm{~d}, J=4 \mathrm{~Hz}, 1 \mathrm{H}), 2.16-$ $2.22(\mathrm{~m}, 1 \mathrm{H}), 1.86-1.96(\mathrm{~m}, 1 \mathrm{H}), 1.29-1.35(\mathrm{~m}, 2 \mathrm{H}), 1.25(\mathrm{~s}, 3 \mathrm{H})$, 0.99 (s, 3H), 0.62 (s, 3H); ${ }^{13} \mathrm{C}$ NMR (100 MHz, $\left.\mathrm{CDCl}_{3}\right) \delta: 182.11$, $161.75,154.87,136.48,135.29,129.63,128.67,125.34,77.36$, 77.04, 76.72, 55.98, 54.22, 49.70, 31.74, 25.96, 19.95, 19.00, 10.03; HR-MS (ESI $\left.{ }^{+}\right): m / z$ calculated for $\mathrm{C}_{18} \mathrm{H}_{20} \mathrm{ClN}_{3}[\mathrm{M}+\mathrm{H}]^{+}$ 314.1424 , found 314.1420 .

3.1.2.7. 4-(2-Bromophenyl)-8,9,9-trimethyl-5, 6,7,8-tetrahydro5,8-methanoquinazolin-2-amine (3g). Yield 88\%; mp 172.5$172.9{ }^{\circ} \mathrm{C} .{ }^{1} \mathrm{H}$ NMR $\left(400 \mathrm{MHz}, \mathrm{CDCl}_{3}\right) \delta: 7.75-7.77(\mathrm{~m}, 2 \mathrm{H}), 7.41-$ $7.48(\mathrm{~m}, 3 \mathrm{H}), 5.28(\mathrm{~s}, 2 \mathrm{H}), 3.07$ (d, $J=4 \mathrm{~Hz}, 1 \mathrm{H}), 2.14-2.22(\mathrm{~m}$, 1H), 1.87-1.94 (m, 1H), 1.32-1.39 (m, 2H), $1.25(\mathrm{~s}, 3 \mathrm{H}), 0.98(\mathrm{~s}$, $3 \mathrm{H}), 0.63(\mathrm{~s}, 3 \mathrm{H}) ;{ }^{13} \mathrm{C} \mathrm{NMR}\left(100 \mathrm{MHz}, \mathrm{CDCl}_{3}\right) \delta: 181.86,161.79$, $156.18,138.05$, 129.18, 128.44, 128.30, 125.48, 55.97, 54.23, 
49.67, 31.80, 26.05, 19.97, 19.04, 10.06; HR-MS $\left(\mathrm{ESI}^{+}\right): \mathrm{m} / \mathrm{z}$ calculated for $\mathrm{C}_{18} \mathrm{H}_{20} \mathrm{BrN}_{3}[\mathrm{M}+\mathrm{H}]^{+} 358.0919$, found 358.0911 .

3.1.2.8. 4-(3-Bromophenyl)-8,9,9-trimethyl-5,6,7,8-tetrahydro5,8-methanoquinazolin-2-amine (3h). Yield 83\%; $\mathrm{mp} 187.2-$ $187.8{ }^{\circ} \mathrm{C} .{ }^{1} \mathrm{H}$ NMR $\left(400 \mathrm{MHz}, \mathrm{CDCl}_{3}\right) \delta: 7.94(\mathrm{t}, J=4 \mathrm{~Hz}, 1 \mathrm{H})$, 7.68, 7.65-7.68 (m, 1H), 7.53-7.56 (m, 1H), $7.32(\mathrm{t}, J=8 \mathrm{~Hz}, 1 \mathrm{H})$, $5.24(\mathrm{~s}, 2 \mathrm{H}), 3.04(\mathrm{~d}, J=4 \mathrm{~Hz}, 1 \mathrm{H}), 2.17-2.23(\mathrm{~m}, 1 \mathrm{H}), 1.93,1.91$, 1.86-1.96 (m, 1H), 1.29-1.36 (m, 2H), 1.25 (s, 3H), 0.99 (s, 3H), $0.63(\mathrm{~s}, 3 \mathrm{H}) ;{ }^{13} \mathrm{C}$ NMR $\left(100 \mathrm{MHz}, \mathrm{CDCl}_{3}\right) \delta: 182.24,161.72$, 154.48, 140.11, 132.14, 131.31, 129.91, 126.87, 125.57, 122.72, 56.00, 54.25, 49.60, 31.73, 25.96, 19.97, 18.99, 10.02; HR-MS $\left(\mathrm{ESI}^{+}\right): m / z$ calculated for $\mathrm{C}_{18} \mathrm{H}_{20} \mathrm{BrN}_{3}[\mathrm{M}+\mathrm{H}]^{+} 358.0919$, found 358.0911 .

3.1.2.9. 4-(4-Bromophenyl)-8,9,9-trimethyl-5, 6, 7,8-tetrahydro5,8-methanoquinazolin-2-amine (3i). Yield 89\%; mp 191.4$191.8{ }^{\circ} \mathrm{C} .{ }^{1} \mathrm{H}$ NMR $\left(400 \mathrm{MHz}, \mathrm{CDCl}_{3}\right) \delta: 7.65(\mathrm{~d}, J=8 \mathrm{~Hz}, 1 \mathrm{H})$, 7.58 (d, $J=8 \mathrm{~Hz}, 1 \mathrm{H}), 5.25$ (s, 2H), 3.02 (d, $J=2 \mathrm{~Hz}, 1 \mathrm{H}), 2.16-$ $2.22(\mathrm{~m}, 1 \mathrm{H}), 1.91(\mathrm{t}, J=12 \mathrm{~Hz}, 1 \mathrm{H}), 1.28-1.35(\mathrm{~m}, 2 \mathrm{H}), 1.25(\mathrm{~s}$, $3 \mathrm{H}), 0.99$ (s, 3H), $0.62(\mathrm{~s}, 3 \mathrm{H}) ;{ }^{13} \mathrm{C}$ NMR (100 MHz, $\left.\mathrm{CDCl}_{3}\right) \delta$ : 182.15, 161.73, 154.90, 136.91, 131.64, 129.90, 125.37, 123.64, 77.36, 77.04, 76.73, 55.99, 54.23, 49.68, 31.73, 25.95, 19.95, 19.01, 10.04; HR-MS $\left(\mathrm{ESI}^{+}\right): \mathrm{m} / z$ calculated for $\mathrm{C}_{18} \mathrm{H}_{20} \mathrm{BrN}_{3}[\mathrm{M}+$ $\mathrm{H}]^{+}$358.0919, found 358.0913.

3.1.2.10. 8,9,9-Trimethyl-4-(o-tolyl)-5, 6,7,8-tetrahydro-5,8methanoquinazolin-2-amine (3j). Yield 88\%; mp 171.9-172.5 ${ }^{\circ} \mathrm{C}$. ${ }^{1} \mathrm{H}$ NMR (400 MHz, $\mathrm{CDCl}_{3}$ ) $\delta: 7.20-7.30(\mathrm{~m}, 3 \mathrm{H}), 7.15(\mathrm{~d}, J=$ $8 \mathrm{~Hz}, 1 \mathrm{H}), 5.39$ (s, 2H), 2.61 (d, $J=4 \mathrm{~Hz}, 1 \mathrm{H}), 2.27$ (s, 3H), 1.98$2.05(\mathrm{~m}, 1 \mathrm{H}), 1.82-1.88(\mathrm{~m}, 1 \mathrm{H}), 1.27-1.33(\mathrm{~m}, 1 \mathrm{H}), 1.24(\mathrm{~s}, 3 \mathrm{H})$, 1.12-1.18 (m, 1H), 0.93 (s, 3H), $0.70(\mathrm{~s}, 3 \mathrm{H}) ;{ }^{13} \mathrm{C}$ NMR $(100 \mathrm{MHz}$, $\left.\mathrm{CDCl}_{3}\right) \delta: 181.13,161.53,158.38,137.51,135.64,130.53,128.41$, 126.91, 125.55, 55.99, 54.61, 48.71, 31.76, 26.26, 19.97, 19.87, 18.94, 9.97; HR-MS (ESI $\left.{ }^{+}\right): m / z$ calculated for $\mathrm{C}_{19} \mathrm{H}_{23} \mathrm{~N}_{3}[\mathrm{M}+\mathrm{H}]^{+}$ 294.1970, found 294.1967.

3.1.2.11. 8,9,9-Trimethyl-4-(m-tolyl)-5, 6,7,8-tetrahydro-5,8methanoquinazolin-2-amine (3k). Yield 86\%; mp 156.8-157.3 ${ }^{\circ} \mathrm{C}$. ${ }^{1} \mathrm{H}$ NMR (400 MHz, $\mathrm{CDCl}_{3}$ ) $\delta: 7.60(\mathrm{~s}, 1 \mathrm{H}), 7.50-7.52(\mathrm{~d}, J=$ $7.6 \mathrm{~Hz}, 1 \mathrm{H}), 7.34(\mathrm{t}, J=8 \mathrm{~Hz}, 1 \mathrm{H}), 7.23(\mathrm{~d}, J=8 \mathrm{~Hz}, 1 \mathrm{H}), 5.24(\mathrm{~s}$, $2 \mathrm{H}), 3.05(\mathrm{~d}, J=4 \mathrm{~Hz}, 1 \mathrm{H}), 2.42(\mathrm{~s}, 3 \mathrm{H}), 2.15-2.21(\mathrm{~m}, 1 \mathrm{H}), 1.87-$ $1.94(\mathrm{~m}, 1 \mathrm{H}), 1.32-1.36(\mathrm{~m}, 2 \mathrm{H}), 1.25(\mathrm{~s}, 3 \mathrm{H}), 0.98(\mathrm{~s}, 3 \mathrm{H}), 0.63(\mathrm{~s}$, $3 \mathrm{H}) ;{ }^{13} \mathrm{C} \mathrm{NMR}\left(100 \mathrm{MHz}, \mathrm{CDCl}_{3}\right) \delta: 181.76,161.75,156.39$, 138.17, 137.98, 129.97, 128.87, 128.25, 125.52, 125.46, 55.96, 54.23, 49.69, 31.80, 26.04, 21.57, 19.97, 19.04, 10.06; HR-MS $\left(\mathrm{ESI}^{+}\right): m / z$ calculated for $\mathrm{C}_{19} \mathrm{H}_{23} \mathrm{~N}_{3}[\mathrm{M}+\mathrm{H}]^{+} 294.1970$, found 294.1967 .

3.1.2.12. 8,9,9-Trimethyl-4-(p-tolyl)-5,6,7,8-tetrahydro-5,8methanoquinazolin-2-amine (3l). Yield 90\%; mp 197.5-197.9 ${ }^{\circ} \mathrm{C}$. ${ }^{1} \mathrm{H} \mathrm{NMR}\left(400 \mathrm{MHz}, \mathrm{CDCl}_{3}\right) \delta: 7.67(\mathrm{~d}, J=8 \mathrm{~Hz}, 2 \mathrm{H}), 7.26(\mathrm{~d}, J=$ $8 \mathrm{~Hz}, 2 \mathrm{H}), 5.24(\mathrm{~s}, 2 \mathrm{H}), 3.06$ (d, $J=4 \mathrm{~Hz}, 1 \mathrm{H}), 2.40$ (s, 3H), 2.14$2.21(\mathrm{~m}, 1 \mathrm{H}), 1.86-1.92(\mathrm{~m}, 1 \mathrm{H}), 1.32-1.35(\mathrm{~m}, 2 \mathrm{H}), 1.24(\mathrm{~s}, 3 \mathrm{H})$, $0.98(\mathrm{~s}, 3 \mathrm{H}), 0.62(\mathrm{~s}, 3 \mathrm{H}) ;{ }^{13} \mathrm{C}$ NMR $\left(100 \mathrm{MHz}, \mathrm{CDCl}_{3}\right) \delta: 181.70$, $161.73,156.20,139.27,135.22$, 129.15, 128.24, 125.26, 77.36, 77.04, 76.72, 55.94, 54.18, 49.74, 31.81, 26.01, 21.38, 19.96, 19.05, 10.07; HR-MS $\left(\right.$ ESI $\left.^{+}\right): m / z$ calculated for $\mathrm{C}_{19} \mathrm{H}_{23} \mathrm{~N}_{3}[\mathrm{M}+\mathrm{H}]^{+}$ 294.1970, found 294.1967.

3.1.2.13. 4-(2-Methoxyphenyl)-8,9,9-trimethyl-5, 6, 7,8tetrahydro-5,8-methanoquinazolin-2-amine (3m). Yield 91\%; mp 175.2-175.8 ${ }^{\circ} \mathrm{C} .{ }^{1} \mathrm{H}$ NMR $\left(400 \mathrm{MHz}, \mathrm{CDCl}_{3}\right) \delta: 7.34-7.41(\mathrm{~m}, 2 \mathrm{H})$, $7.03(\mathrm{t}, J=8 \mathrm{~Hz}, 1 \mathrm{H}), 6.95(\mathrm{~d}, J=8 \mathrm{~Hz}, 1 \mathrm{H}), 5.32(\mathrm{~s}, 2 \mathrm{H}), 3.78(\mathrm{~s}$, $3 \mathrm{H}), 2.63(\mathrm{~d}, J=4 \mathrm{~Hz}, 1 \mathrm{H}), 1.97-2.03(\mathrm{~m}, 1 \mathrm{H}), 1.81-1.87(\mathrm{~m}, 1 \mathrm{H})$, 1.27-1.33 (m, 1H), 1.23 (s, 3H), $0.94(\mathrm{~s}, 3 \mathrm{H}), 0.65(\mathrm{~s}, 3 \mathrm{H}) ;{ }^{13} \mathrm{C}$ NMR (100 MHz, $\left.\mathrm{CDCl}_{3}\right) \delta: 180.39,161.87,156.61,154.90$, 130.60, 130.08, 128.08, 127.44, 120.80, 111.00, 55.91, 55.17, 54.47, 49.71, 32.01, 25.65, 19.85, 19.07, 10.07; HR-MS (ESI $\left.{ }^{+}\right): m / z$ calculated for $\mathrm{C}_{19} \mathrm{H}_{23} \mathrm{~N}_{3} \mathrm{O}[\mathrm{M}+\mathrm{H}]^{+} 310.1919$, found 310.1915 .

3.1.2.14. 4-(3-Methoxyphenyl)-8,9,9-trimethyl-5,6,7,8-

tetrahydro-5,8-methanoquinazolin-2-amine (3n). Yield 90\%; mp 183.2-183.4 ${ }^{\circ} \mathrm{C} .{ }^{1} \mathrm{H}$ NMR (400 MHz, $\left.\mathrm{CDCl}_{3}\right) \delta: 7.31-7.38(\mathrm{~m}, 3 \mathrm{H})$, 6.95-6.98 (m, 1H), 5.27 (s, 2H), 3.87 (s, 3H), 3.07 (d, $J=4 \mathrm{~Hz}$, $1 \mathrm{H}), 2.15-2.21(\mathrm{~m}, 1 \mathrm{H}), 1.87-1.92(\mathrm{~m}, 1 \mathrm{H}), 1.32-1.36(\mathrm{~m}, 2 \mathrm{H})$, $1.25(\mathrm{~s}, 3 \mathrm{H}), 0.98(\mathrm{~s}, 3 \mathrm{H}), 0.63(\mathrm{~s}, 3 \mathrm{H}) ;{ }^{13} \mathrm{C} \mathrm{NMR}\left(100 \mathrm{MHz}, \mathrm{CDCl}_{3}\right)$ $\delta: 181.91,161.74,159.72,155.99,139.43,129.40,125.52,120.78$, 115.07, 113.58, 55.94, 55.32, 54.24, 49.74, 31.80, 25.99, 19.97, 19.02, 10.05; HR-MS $\left(\mathrm{ESI}^{+}\right): \mathrm{m} / z$ calculated for $\mathrm{C}_{19} \mathrm{H}_{23} \mathrm{~N}_{3} \mathrm{O}[\mathrm{M}+$ $\mathrm{H}]^{+} 310.1919$, found 310.1919 .

3.1.2.15. 4-(4-Methoxyphenyl)-8,9,9-trimethyl-5,6,7,8-

tetrahydro-5,8-methanoquinazolin-2-amine (3o). Yield 93\%; mp 131.7-131.9 ${ }^{\circ} \mathrm{C} .{ }^{1} \mathrm{H}$ NMR (400 $\left.\mathrm{MHz}, \mathrm{CDCl}_{3}\right) \delta: 7.75(\mathrm{~d}, J=8 \mathrm{~Hz}$, $2 \mathrm{H}), 6.98(\mathrm{~d}, J=8 \mathrm{~Hz}, 2 \mathrm{H}), 5.27(\mathrm{~s}, 2 \mathrm{H}), 3.85(\mathrm{~s}, 3 \mathrm{H}), 3.06(\mathrm{~d}, J=$ $4 \mathrm{~Hz}, 1 \mathrm{H}), 2.14-2.21$ (m, 1H), 1.86-1.94 (m, 1H), 1.31-1.35 (m, $2 \mathrm{H}), 1.24(\mathrm{~s}, 3 \mathrm{H}), 0.98(\mathrm{~s}, 3 \mathrm{H}), 0.63(\mathrm{~s}, 3 \mathrm{H}) ;{ }^{13} \mathrm{C}$ NMR $(100 \mathrm{MHz}$, $\left.\mathrm{CDCl}_{3}\right) \delta: 181.59,161.72,160.54,155.82,130.61,129.76,124.81$, 113.85, 55.91, 55.33, 54.12, 49.83, 31.83, 25.97, 19.96, 19.06, 10.08; HR-MS (ESI $\left.{ }^{+}\right): m / z$ calculated for $\mathrm{C}_{19} \mathrm{H}_{23} \mathrm{~N}_{3} \mathrm{O}[\mathrm{M}+\mathrm{H}]^{+}$ 310.1919 , found 310.1916 .

3.1.2.16. 2-(2-Amino-8,9,9-trimethyl-5,6,7,8-tetrahydro-5,8methanoquinazolin-4-yl)phenol (3p). Yield 89\%; mp 167.9168.3 ${ }^{\circ} \mathrm{C} .{ }^{1} \mathrm{H}$ NMR $\left(400 \mathrm{MHz}, \mathrm{CDCl}_{3}\right) \delta: 7.65(\mathrm{~d}, J=8 \mathrm{~Hz}, 1 \mathrm{H})$, $7.31(\mathrm{t}, J=8 \mathrm{~Hz}, 1 \mathrm{H}), 7.0(\mathrm{~d}, J=8 \mathrm{~Hz}, 1 \mathrm{H}), 6.9(\mathrm{~d}, J=16 \mathrm{~Hz}, 1 \mathrm{H})$, $5.21(\mathrm{~s}, 2 \mathrm{H}), 3.27$ (d, $J=4 \mathrm{~Hz}, 1 \mathrm{H}), 2.21-2.29(\mathrm{~m}, 1 \mathrm{H}), 1.90-1.96$ (m, 1H), 1.31-1.43 (m, 2H), $1.24(\mathrm{~s}, 3 \mathrm{H}), 1.00(\mathrm{~s}, 3 \mathrm{H}), 0.63(\mathrm{~s}, 3 \mathrm{H})$; ${ }^{13} \mathrm{C}$ NMR (100 MHz, $\left.\mathrm{CDCl}_{3}\right): \delta 183.33,159.85,159.01,155.66$, 131.66, 129.11, 123.93, 119.21, 118.64, 118.22, 55.72, 54.22, 50.86, 31.88, 25.35, 19.94, 18.99, 10.03; HR-MS $\left(\mathrm{ESI}^{+}\right): \mathrm{m} / \mathrm{z}$ calculated for $\mathrm{C}_{18} \mathrm{H}_{21} \mathrm{~N}_{3} \mathrm{O}[\mathrm{M}+\mathrm{H}]^{+}$296.1763, found 296.1758.

3.1.2.17. 3-(2-Amino-8,9,9-trimethyl-5, 6, 7,8-tetrahydro-5,8methanoquinazolin-4-yl)phenol (3q). Yield 87\%; $\mathrm{mp} 262.0-$ $262.8^{\circ} \mathrm{C} .{ }^{1} \mathrm{H}$ NMR $\left(400 \mathrm{MHz}, \mathrm{DMSO}-d_{6}\right) \delta: 9.32$ (s, 1H), 6.92-7.04 $(\mathrm{m}, 3 \mathrm{H}), 6.59(\mathrm{~d}, J=8 \mathrm{~Hz}, 1 \mathrm{H}), 6.10(\mathrm{~s}, 2 \mathrm{H}), 2.78(\mathrm{~d}, J=4 \mathrm{~Hz}, 1 \mathrm{H})$, 1.89-1.94 (m, 1H), 1.60-1.65 (m, 1H), 0.94-1.03 (m, 2H), 0.90 (s, $3 \mathrm{H}), 0.70$ (s, 3H), 0.31 (s, 3H); ${ }^{13} \mathrm{C}$ NMR (100 MHz, DMSO- $\left.d_{6}\right)$ : $\delta 180.89,161.97,157.31,154.84,139.11,129.28,123.15,118.75$, 116.10, 114.81, 55.00, 53.62, 49.26, 31.62, 25.84, 19.65, 18.68, 10.19; HR-MS $\left(\right.$ ESI $\left.^{+}\right): m / z$ calculated for $\mathrm{C}_{18} \mathrm{H}_{21} \mathrm{~N}_{3} \mathrm{O}[\mathrm{M}+\mathrm{H}]^{+}$ 296.1763, found 296.1761 .

3.1.2.18. 4-(2-Amino-8,9,9-trimethyl-5, 6,7,8-tetrahydro-5,8methanoquinazolin-4-yl)phenol (3r). Yield 89\%; mp 264.1$264.8{ }^{\circ} \mathrm{C} .{ }^{1} \mathrm{H}$ NMR $\left(400 \mathrm{MHz}, \mathrm{DMSO}-d_{6}\right) \delta: 9.79(\mathrm{~s}, 1 \mathrm{H}), 7.65(\mathrm{~d}, J$ $=8 \mathrm{~Hz}, 2 \mathrm{H}), 6.87(\mathrm{~d}, J=8 \mathrm{~Hz}, 2 \mathrm{H}), 6.26(\mathrm{~s}, 2 \mathrm{H}), 3.04(\mathrm{~d}, J=4 \mathrm{~Hz}$, $1 \mathrm{H}), 2.13-2.18(\mathrm{~m}, 1 \mathrm{H}), 1.83-1.89(\mathrm{~m}, 1 \mathrm{H}), 1.17-1.25(\mathrm{~m}, 2 \mathrm{H})$, $1.14(\mathrm{~s}, 3 \mathrm{H}), 0.94(\mathrm{~s}, 3 \mathrm{H}), 0.56(\mathrm{~s}, 3 \mathrm{H}) ;{ }^{13} \mathrm{C}$ NMR $(100 \mathrm{MHz}$, DMSO- $\left.d_{6}\right): \delta 180.56,161.87,158.52,154.75,129.49,128.62$, 122.24, 115.12, 54.95, 53.50, 49.33, 31.59, 25.77, 19.66, 18.72, 10.22; HR-MS $\left(\mathrm{ESI}^{+}\right): \mathrm{m} / \mathrm{z}$ calculated for $\mathrm{C}_{18} \mathrm{H}_{21} \mathrm{~N}_{3} \mathrm{O}[\mathrm{M}+\mathrm{H}]^{+}$ 296.1763, found 296.1759. 
3.1.2.19. 8,9,9-Trimethyl-4-(pyridin-2-yl)-5,6,7,8-tetrahydro5,8-methanoquinazolin-2-amine (3s). Yield 89\%; mp 174.7175.2 ${ }^{\circ} \mathrm{C} .{ }^{1} \mathrm{H}$ NMR $\left(400 \mathrm{MHz}, \mathrm{CDCl}_{3}\right) \delta: 8.72(\mathrm{~d}, J=8 \mathrm{~Hz}, 1 \mathrm{H})$, $8.10(\mathrm{~d}, J=8 \mathrm{~Hz}, 1 \mathrm{H}), 7.76-7.80(\mathrm{~m}, 1 \mathrm{H}), 7.29-7.31(\mathrm{~m}, 1 \mathrm{H}), 5.18$ (s, 2H), $3.62(\mathrm{~d}, J=4 \mathrm{~Hz}, 1 \mathrm{H}), 2.15-2.21(\mathrm{~m}, 1 \mathrm{H}), 1.85-1.93(\mathrm{~m}$, 1H), $1.28-1.36(\mathrm{~m}, 2 \mathrm{H}), 1.26(\mathrm{~s}, 3 \mathrm{H}), 1.00(\mathrm{~s}, 3 \mathrm{H}), 0.65(\mathrm{~s}, 3 \mathrm{H}) ;{ }^{13} \mathrm{C}$ NMR (100 MHz, DMSO- $d_{6}$ ): $\delta$ 177.83, 156.26, 151.19, 148.60, $144.14,131.07,121.59,118.33,117.43,72.10,71.78,71.46$, 50.06, 48.96, 44.84, 26.70, 20.51, 14.84, 13.70, 4.80; HR-MS $\left(\mathrm{ESI}^{+}\right): m / z$ calculated for $\mathrm{C}_{17} \mathrm{H}_{20} \mathrm{~N}_{4}[\mathrm{M}+\mathrm{H}]^{+} 281.1766$, found 281.1760 .

3.1.2.20. 8,9,9-Trimethyl-4-(pyridin-3-yl)-5,6,7,8-tetrahydro5,8-methanoquinazolin-2-amine (3t). Yield 85\%; mp 197.2$197.7^{\circ} \mathrm{C} .{ }^{1} \mathrm{H}$ NMR $\left(400 \mathrm{MHz}, \mathrm{CDCl}_{3}\right.$ ) $\delta: 8.99$ (s, 1H), 8.66, 8.65 (d, $J=4 \mathrm{~Hz}, 1 \mathrm{H}), 8.13(\mathrm{~d}, J=8 \mathrm{~Hz}, 1 \mathrm{H}), 7.39-7.42(\mathrm{~m}, 1 \mathrm{H}), 5.25$ (s, $2 \mathrm{H}), 3.07$ (d, $J=4 \mathrm{~Hz}, 1 \mathrm{H}), 2.19-2.29(\mathrm{~m}, 1 \mathrm{H}), 1.90-1.97(\mathrm{~m}, 1 \mathrm{H})$, $1.34(\mathrm{~d}, J=8 \mathrm{~Hz}, 1 \mathrm{H}), 1.26(\mathrm{~s}, 3 \mathrm{H}), 1.00(\mathrm{~s}, 3 \mathrm{H}), 0.64(\mathrm{~s}, 3 \mathrm{H}) ;{ }^{13} \mathrm{C}$ NMR $\left(100 \mathrm{MHz}, \mathrm{CDCl}_{3}\right): \delta 182.34,161.82,153.16,150.10$, 149.46, 135.60, 133.74, 125.83, 123.45, 56.07, 54.28, 49.59, 31.65, 26.04, 19.96, 18.97, 9.99; HR-MS $\left(\mathrm{ESI}^{+}\right): \mathrm{m} / z$ calculated for $\mathrm{C}_{17} \mathrm{H}_{20} \mathrm{~N}_{4}[\mathrm{M}+\mathrm{H}]^{+}$281.1766, found 281.1762.

3.1.2.21. 8,9,9-Trimethyl-4-(pyridin-4-yl)-5,6,7,8-tetrahydro5,8-methanoquinazolin-2-amine (3u). Yield 90\%; mp 207.9$208.1{ }^{\circ} \mathrm{C} .{ }^{1} \mathrm{H}$ NMR $\left(400 \mathrm{MHz}, \mathrm{CDCl}_{3}\right) \delta: 8.72(\mathrm{~d}, J=4 \mathrm{~Hz}, 2 \mathrm{H})$, $7.66(\mathrm{~d}, J=4 \mathrm{~Hz}, 2 \mathrm{H}), 5.35$ (s, 2H), 3.08 (d, $J=4 \mathrm{~Hz}, 1 \mathrm{H}), 2.19-$ 2.25 (m, 1H), 1.89-1.98 (m, 1H), 1.30-1.37 (m, 2H), 1.26 (s, 3H), $1.01(\mathrm{~s}, 3 \mathrm{H}), 0.63(\mathrm{~s}, 3 \mathrm{H}) ;{ }^{13} \mathrm{C}$ NMR $\left(100 \mathrm{MHz}, \mathrm{CDCl}_{3}\right): \delta 182.70$, 161.85 , 153.26, 150.16, 145.40, 126.10, 122.52, 56.00, 54.27, 49.55, 31.67, 25.93, 19.96, 18.94, 9.96; HR-MS $\left(\mathrm{ESI}^{+}\right): \mathrm{m} / \mathrm{z}$ calculated for $\mathrm{C}_{17} \mathrm{H}_{20} \mathrm{~N}_{4}[\mathrm{M}+\mathrm{H}]^{+} 281.1766$, found 281.1763 .

3.1.2.22. 4-(4-(Dimethylamino)phenyl)-8,9,9-trimethyl-5,6,7,8tetrahydro-5,8-methanoquinazolin-2-amine (3v). Yield 93\%; mp 198.1-198.6 ${ }^{\circ} \mathrm{C} .{ }^{1} \mathrm{H}$ NMR $\left(400 \mathrm{MHz}, \mathrm{CDCl}_{3}\right) \delta: 7.76(\mathrm{~d}, J=8 \mathrm{~Hz}$, $2 \mathrm{H}), 6.79$ (d, $J=8 \mathrm{~Hz}, 2 \mathrm{H}), 5.24(\mathrm{~s}, 2 \mathrm{H}), 3.12(\mathrm{~d}, J=4 \mathrm{~Hz}, 1 \mathrm{H})$, $3.03(\mathrm{~s}, 2 \mathrm{H}), 2.17-2.22(\mathrm{~m}, 1 \mathrm{H}), 1.87-1.92(\mathrm{~m}, 1 \mathrm{H}), 1.30-1.41(\mathrm{~m}$, $2 \mathrm{H}), 1.25$ (s, 3H), 0.99 (s, 3H), $0.64(\mathrm{~s}, 3 \mathrm{H}) ;{ }^{13} \mathrm{C}$ NMR $(100 \mathrm{MHz}$, $\left.\mathrm{CDCl}_{3}\right): \delta 181.14,161.65,156.35,151.15,129.47,125.73,124.28$, 111.77, 55.84, 54.00, 50.01, 40.29, 31.92, 25.94, 19.97, 19.11, 10.12; HR-MS $\left(\mathrm{ESI}^{+}\right): \mathrm{m} / \mathrm{z}$ calculated for $\mathrm{C}_{20} \mathrm{H}_{26} \mathrm{~N}_{4}[\mathrm{M}+\mathrm{H}]^{+}$ 323.2236, found 323.2231.

3.1.2.23. 8,9,9-Trimethyl-4-(4-nitrophenyl)-5,6,7,8-tetrahydro5,8-methanoquinazolin-2-amine (3w). Yield 82\%; $\mathrm{mp}$ 138.7$139.1{ }^{\circ} \mathrm{C} .{ }^{1} \mathrm{H}$ NMR $\left(400 \mathrm{MHz}, \mathrm{CDCl}_{3}\right) \delta: 8.33(\mathrm{~d}, J=8 \mathrm{~Hz}, 2 \mathrm{H})$, $7.97(\mathrm{~d}, J=8 \mathrm{~Hz}, 2 \mathrm{H}), 5.07$ (s, 2H), 3.07 (d, $J=4 \mathrm{~Hz}, 1 \mathrm{H}), 2.22-$ $2.25(\mathrm{~m}, 1 \mathrm{H}), 1.94(\mathrm{~m}, 1 \mathrm{H}), 1.33-1.40(\mathrm{~m}, 1 \mathrm{H}), 1.28$ (s, 3H), 1.03 $(\mathrm{s}, 3 \mathrm{H}), 0.65(\mathrm{~s}, 3 \mathrm{H}) ;{ }^{13} \mathrm{C} \mathrm{NMR}\left(100 \mathrm{MHz}, \mathrm{CDCl}_{3}\right): \delta$ 182.76, 161.66, 153.40, 145.72, 142.31, 130.14, 126.27, 123.90, 57.19, 49.33, 46.65, 30.46, 25.92, 20.64, 18.19, 9.21; HR-MS (ESI $\left.{ }^{+}\right): m / z$ calculated for $\mathrm{C}_{18} \mathrm{H}_{20} \mathrm{~N}_{4} \mathrm{O}_{2}[\mathrm{M}+\mathrm{H}]^{+}$325.1665, found 325.1659.

3.1.2.24. 8,9,9-Trimethyl-4-phenyl-5,6,7,8-tetrahydro-5,8methanoquinazolin-2-amine (3x). Yield 94\%; mp 172.9-173.2 ${ }^{\circ} \mathrm{C}$. ${ }^{1} \mathrm{H}$ NMR (400 MHz, $\mathrm{CDCl}_{3}$ ) $\delta: 7.75-7.77$ (m, 2H), 7.41-7.48 (m, $3 \mathrm{H}), 5.33(\mathrm{~s}, 2 \mathrm{H}), 3.06(\mathrm{~d}, J=4 \mathrm{~Hz}, 1 \mathrm{H}), 2.16-2.21(\mathrm{~m}, 1 \mathrm{H}), 1.87-$ $1.92(\mathrm{~m}, 1 \mathrm{H}), 1.32-1.35(\mathrm{~m}, 2 \mathrm{H}), 1.25(\mathrm{~s}, 3 \mathrm{H}), 0.98(\mathrm{~s}, 3 \mathrm{H}), 0.63$ (s, $3 \mathrm{H}) ;{ }^{13} \mathrm{C} \mathrm{NMR}\left(100 \mathrm{MHz}, \mathrm{CDCl}_{3}\right): \delta$ 181.85, 161.81, 156.19, 138.05, 129.18, 128.43, 128.30, 125.45, 55.96, 54.24, 49.67,
31.80, 26.05, 19.97, 19.04, 10.07. HR-MS $\left(\mathrm{ESI}^{+}\right): \mathrm{m} / \mathrm{z}$ calculated for $\mathrm{C}_{18} \mathrm{H}_{21} \mathrm{~N}_{3}[\mathrm{M}+\mathrm{H}]^{+} 280.1814$, found 280.1810 .

\subsection{Cell imaging}

3.2.1. Cells culture. The cells (MDA-MB-231, RPMI-8226, A549, and GES-1) were supplied by the Cell Bank of the Chinese Academy of Sciences. The cells were cultured in RPMI1640 medium (Gibco) supplemented with 5\% fetal bovine serum (FBS, Gibco), 1\% penicillin and streptomycin (Gibco) in a humidified atmosphere with $5 \% \mathrm{CO}_{2}$ at $37{ }^{\circ} \mathrm{C}$. The medium was updated every two days. After reaching about $70-80 \%$ confluence, cells were trypsinized and harvested for further process. Stock solutions of the candidate compounds (50 mM) were prepared in DMSO.

3.2.2. MTS assay. Cell cytotoxicity was evaluated by the MTS assay. Briefly, the harvested cells were seeded in 96-well plates at density of $1 \times 10^{5}$ cells per well and incubated overnight for adherence. Fresh medium with different concentrations of the candidate compounds were added into cells in triplicate, and etoposide and assay medium were treated as positive and blank controls respectively. The final concentration of DMSO in the well was kept at $0.1 \%$ in overall experiment. Upon complication of $72 \mathrm{~h}$ incubation, $10 \mu \mathrm{L}$ MTS solution was added to each well and incubated for additional $0.5-1 \mathrm{~h}$ under same condition. Thereafter, the plates were gently mixed and the optical density (OD) was measured on a microplate reader at a wavelength of $490 \mathrm{~nm}$. The percentage of inhibition was calculated by using the below equation, and the values of $\mathrm{IC}_{50}$ were analyzed through GraphPad Prism 5.

$$
\text { Inhibition rate }(\%)=\frac{\mathrm{OD}_{\text {drug }}-\mathrm{OD}_{\text {blank }}}{\mathrm{OD}_{\text {control }}-\mathrm{OD}_{\text {blank }}} \times 100 \%
$$

3.2.3. Annexin V-APC/7-ADD apoptosis assay. Cellular apoptosis was measured by flow cytometry using Annexin VAPC/7-AAD double staining cell apoptosis detection kit. MDAMB-231 cell suspensions in the logarithmic growth phase were seeded into a 6 -well plates at $2 \times 10^{5}$ cells per well. After incubation overnight, the adherent cells were exposed to different concentrations $(2.5,5$, and $10 \mu \mathrm{M})$ of compound $3 \mathbf{f}$ for $72 \mathrm{~h}$. Then cells were harvested and centrifuged (2000 rpm, 5 min) to discard supernatant, followed by washing twice with cold PBS. Subsequently, binding buffer $(500 \mu \mathrm{L})$ and Annexin VAPC $(5 \mu \mathrm{L})$ were added and the cell mixture was incubated at room temperature in the dark for 15 minutes. Prior to analysis using flow cytometer, $5 \mu \mathrm{L}$ of 7-AAD was applied to stain cells for 5 minutes.

3.2.4. Cell cycle assay. Cell cycle phase distribution was evaluated by measuring the cellular DNA content with flow cytometer. MDA-MB-231 cells $\left(2 \times 10^{5}\right.$ per well $)$ were plated in a 6-well culture plate and incubated at $37^{\circ} \mathrm{C}$ for $24 \mathrm{~h}$. Then the medium was removed and replaced with freshly prepared solution of the tested compound $3 \mathbf{f}$ at different concentrations $(2.5,5$, and $10 \mu \mathrm{M})$. After exposure for $72 \mathrm{~h}$, the cells were washed twice with PBS, collected by centrifugation, and fixed in ice-cold $70 \%$ ethanol at $4{ }^{\circ} \mathrm{C}$ for a whole night. Afterwards, the 
cells were washed with pure PBS and resuspended in PBS mixture containing RNase $\mathrm{A}\left(1 \mathrm{mg} \mathrm{ml}^{-1}\right)$ and propidium iodide (PI) $\left(10 \mathrm{mg} \mathrm{ml}^{-1}\right)$. Half an hour later, the DNA content in samples was analysed immediately by flow cytometry.

3.2.5. Mitochondrial membrane potential assay. The loss of the mitochondrial potential during apoptosis was assayed by flow cytometry using dye JC-1 $\left(5,5^{\prime}, 6,6^{\prime}\right.$-tetrachloro-1, $1^{\prime}, 3,3^{\prime}$ tetrethylbenzimidalylcarbocyanineiodide). MDA-MB-231 cells were cultured in 6-well plate for $72 \mathrm{~h}$ prior exposure to $2.5,5$, and $10 \mu \mathrm{M}$ compound $3 \mathbf{f}$ for $24 \mathrm{~h}$, cells without $3 \mathrm{f}$ treatment were used as a control. Following treatment, the collected cells were washed with cold PBS (phosphate buffer, $\mathrm{pH}=7.4$ ) twice, then JC-1 working solution was added to each tube and the cells were allowed for incubation at $37{ }^{\circ} \mathrm{C}$ in darkness. Finally, fluorescent intensity of JC- 1 was determined by flow cytometry after another two times wash with PBS.

3.2.6. Analysis of reactive oxygen species. Effects of compound $3 \mathbf{f}$ on ROS generation were assessed by flow cytometry using DCFH-DA as fluorescent probe. MDA-MB-231 cells were seeded in a 6-well plate with $1 \times 10^{6}$ cells each well, and incubated overnight. Subsequently, cells were treated with compound $3 \mathrm{f}$ at different concentration $(2.5,5$, or $10 \mu \mathrm{M})$ or vehicle alone as a control. After $24 \mathrm{~h}$ treatment, the medium was changed to serum-free medium containing $10 \mu \mathrm{M}$ of DCFH-DA and incubated at $37{ }^{\circ} \mathrm{C}$ in the dark for $20-30 \mathrm{~min}$. The intracellular ROS accumulation was quantified by measuring DCF fluorescent intensity on flow cytometry. To investigate the role of ROS in compound $3 \mathbf{f}$ induced cell apoptosis, $N$-acetylcysteine (NAC, $5 \mathrm{mM}$ ) which as a ROS inhibitor was added to culture medium prior to the treatment with compound $3 \mathbf{f}(5 \mu \mathrm{M})$.

3.2.7. Western blot analysis. MDA-MB-231 cells were reacted with compound $3 \mathrm{f}$ at indicated concentrations $(0,2.5,5$, and $10 \mu \mathrm{M}$ ) for $72 \mathrm{~h}$, then collected cells were washed twice with PBS and lysed in ice-cold lysis buffer over $30 \mathrm{~min}$. The supernatant was obtained from lysate which was centrifuged for $15 \mathrm{~min}$ at $4{ }^{\circ} \mathrm{C}$. The BCA Protein Assay Kit was used for determining the protein contents, while SDS-PAGE gel electrophoresis was employed to separate proteins according to their molecular weight. After being transferred to a nitrocellulose membrane, the protein was blocked in TBST buffer with $5 \%$ skim milk at room temperature for $60 \mathrm{~min}$. Subsequently, the membranes were incubated with appropriate primary antibodies overnight at $4{ }^{\circ} \mathrm{C}$. Thenceforth, the membranes were rinsed three times with TBST and allowed for incubated with secondary antibodies at $25{ }^{\circ} \mathrm{C}$ for $1 \mathrm{~h}$. Clean the membrane again and the blots were visualized via an improved chemiluminescence detection reagent, while the amount of proteins of each lane was indicated by $\beta$-actin.

\section{Conclusion}

In summary, we synthesized a series of novel pyrimidine derivatives based on camphor and evaluated their anticancer activities against three human cancer cell lines (MDA-MB-231, RPMI-8226, and A549). The majority of synthesized compounds possessed moderate to good growth inhibition, particularly, compound $3 \mathbf{f}$ appeared to be the most active comparable to etoposide, and had much lower cytotoxicity to normal GES-1 cells $\left(\mathrm{IC}_{50}>50 \mu \mathrm{M}\right)$ than the reference drug $\left(\mathrm{IC}_{50}\right.$ $=8.89 \mu \mathrm{M})$. Meanwhile, the overall result suggested that electron-withdrawing group at para-position on aromatic rings is crucial for cytotoxicity. Subsequently, compound 3 f was selected for further anticancer mechanisms in a battery of assays. Flow cytometry experiments demonstrated that compound 3f induced G0/G1 phase arrest and apoptosis in MDA-MB-231 cells, and the DCFH-DA assays revealed that apoptosis was mediated through intracellular ROS stimulation. Moreover, compound $3 \mathbf{f}$ could also cause the depolarization of mitochondrial membrane potentials, which indicated that compound 3f could activate the mitochondrial apoptosis pathway. This mechanistic pathway was confirmed by upregulation of pro-apoptotic proteins Bax, cytochrome $\mathrm{C}$ and caspase3 , whereas the expression of anti-apoptosis protein Bcl-2 was downregulated. On the basis of above studies, it can be concluded that compound $3 \mathbf{f}$ exhibited potent anticancer efficiency via ROS-mediated mitochondrial apoptosis pathway. So far, plenty of designed compounds against breast cancer cell, including ones based on pyrimidine rings, have been reported, and their anti-tumor mechanism is mostly related to mitochondrial apoptosis pathway. ${ }^{39-41}$ However, there is no effective drug for triple-negative breast cancer (MDA-MB-231) because of its high metastasis and drug resistance. We hope these findings in this paper will provide some valuable hints for exploring more effective drugs for breast cancer therapy.

\section{Conflicts of interest}

The authors declare no competing interests.

\section{Acknowledgements}

This study was supported by the National Natural Science Foundation of China (No. 31470592), Major Project of Jiangsu Province University Natural Science (No.14KJ220001) and Open Funding of Jiangsu Key Laboratory of Biomass Energy and Materials (No. JSBEM2014010). Besides, sincere gratitude to Jiangsu Chia Tai Fenghai Pharmaceutical Co. Ltd for support in cytotoxicity evaluation assay.

\section{References}

1 B. Vainshelboim, J. Müller, R. M. Lima, K. T. Nead, C. Chester, K. Chan, P. Kokkinos and J. Myers, Prev. Med., 2017, 100, 89-94.

2 K. Yang, Y. Li, Q. Tang, L. Zheng and D. He, Eur. J. Med. Chem., 2019, 170, 45-54.

3 D. Wan, B. Tang, Y. J. Wang, B. H. Guo, H. Yin, Q. Y. Yi and Y. J. Liu, Eur. J. Med. Chem., 2017, 139, 180-190.

4 S. Gupta, G. E. Kass, E. Szegezdi and B. Joseph, J. Cell. Mol. Med., 2009, 13, 1004-1033.

5 Z. Jin and W. S. El-Deiry, Cancer Biol. Ther., 2005, 4, 139-163.

6 J. C. Martinou, S. Desagher and B. Antonsson, Nat. Cell Biol., 2000, 2, 41-43. 
7 P. Giuseppe, F. M. Ruggiero and P. Giuseppe, FASEB J., 2003, 17, 2202.

8 S. Xiong, T. Mu, G. Wang and X. Jiang, Protein Cell, 2014, 5, 737-749.

9 E. Finkel, Science, 2001, 292, 624-626.

10 S. Cherukupalli, G. A. Hampannavar, S. Chinnam, B. Chandrasekaran, N. Sayyad, F. Kayamba, A. R. Reddy and R. Karpoormath, Bioorg. Med. Chem., 2018, 26, 309-339.

11 A. M. Fargualy, N. S. Habib, K. A. Ismail, A. M. M. Hassan and M. T. M. Sarg, ChemInform, 2013, 66, 276-295.

12 Y. Ouyang, W. Zou, L. Peng, Z. Yang, Q. Tang, M. Chen, S. Jia, H. Zhang, Z. Lan and P. Zheng, Eur. J. Med. Chem., 2018, 154, 29-43.

13 M. Allam, A. K. D. Bhavani, A. Mudiraj, N. Ranjan, M. Thippana and P. P. Babu, Eur. J. Med. Chem., 2018, 156, 43-52.

14 Y. Yi, G. Yang, Z. Chao, J. Chen, J. Liang and R. Shang, Eur. J. Med. Chem., 2015, 101, 179-184.

15 E. Scocchera, S. M. Reeve, S. Keshipeddy, M. N. Lombardo, B. Hajian, A. E. Sochia, J. B. Alverson, N. D. Priestley, A. C. Anderson and D. L. Wright, ACS Med. Chem. Lett., 2016, 7, 692-696.

16 P. Gao, L. Zhang, L. Sun, T. Huang, J. Tan, J. Zhang, Z. Zhou, T. Zhao, L. Menéndez-Arias and C. Pannecouque, Bioorg. Med. Chem., 2017, 25, 5779-5789.

17 M. Krečmerová, M. Dračínský, R. Snoeck, J. Balzarini, K. Pomeisl and G. Andrei, Bioorg. Med. Chem., 2017, 25, 4637-4648.

18 J. Wang, L. Zhang, J. Zhao, Y. Zhang, Q. Liu, C. Tian, Z. Zhang, J. Liu and X. Wang, Bioorg. Med. Chem., 2018, 100, 89-94.

19 E. S. Zuniga, A. Korkegian, S. Mullen, E. J. Hembre, P. L. Ornstein, G. Cortez, K. Biswas, N. Kumar, J. Cramer and T. Masquelin, Bioorg. Med. Chem., 2017, 25, 3922-3946.

20 P. S. Shirude, B. Paul, C. N. Roy, C. Kedari, B. Bandodkar and B. G. Ugarkar, ACS Med. Chem. Lett., 2012, 3, 736-740.

21 K. Shah, X. Lin, S. F. Queener, V. Cody, J. Pace and A. Gangjee, Bioorg. Med. Chem., 2018, 26, 2640-2650.

22 D. Giles, K. Roopa, F. R. Sheeba, P. M. Gurubasavarajaswamy, G. Divakar and T. Vidhya, Eur. J. Med. Chem., 2012, 58, 478-484.

23 H. Kaur, J. Balzarini, C. D. Kock, P. J. Smith, K. Chibale and K. Singh, Eur. J. Med. Chem., 2015, 101, 52-62.
24 S. Manohar, U. C. Rajesh, S. I. Khan, B. L. Tekwani and D. S. Rawat, ACS Med. Chem. Lett., 2012, 3, 555-559.

25 Z. Yang, Y. Fang and H. Park, Bioorg. Med. Chem. Lett., 2017, 27, 2515-2519.

26 R. S. Keri, K. M. Hosamani, R. V. Shingalapur and M. H. Hugar, ChemInform, 2010, 45, 2597-2605.

27 Y. Addepalli, X. Yang, M. Zhou, D. P. Reddy, S. L. Zhang, Z. Wang and Y. He, Eur. J. Med. Chem., 2018, 151, 214-225.

28 G. Joshi, H. Nayyar, S. Kalra, P. Sharma, A. Munshi, S. Singh and R. Kumar, Chem. Biol. Drug Des., 2017, 90, 995-1006.

29 M. Murahari, K. V. Prakash, G. J. Peters and Y. C. Mayur, Eur. J. Med. Chem., 2017, 139, 961-981.

30 G. Luo, Z. Tang, K. Lao, X. Li, Q. You and H. Xiang, Eur. J. Med. Chem., 2018, 150, 783-795.

31 M. Coffinet, F. Massicot, J. Joseph, J. B. Behr, F. Jaroschik and J. L. Vasse, Chem. Commun., 2016, 53, 111-114.

32 G. Blay, V. Hernández-Olmos and J. R. Pedro, ChemInform, 2008, 40, 4840-4842.

33 F. W. Lewis, T. C. Mccabe and D. H. Grayson, Tetrahedron, 2011, 67, 7517-7528.

34 Y. Wang, J. Busch-Petersen, F. Wang, T. J. Kiesow, T. L. Graybill, J. Jin, Z. Yang, J. J. Foley, G. E. Hunsberger and D. B. Schmidt, Bioorg. Med. Chem. Lett., 2009, 19, 114118.

35 S. O. Kuranov, I. P. Tsypysheva, M. V. Khvostov, L. F. Zainullina, S. S. Borisevich, Y. V. Vakhitova, O. A. Luzina and N. F. Salakhutdinov, Bioorg. Med. Chem., 2018, 26, 4402-4409.

36 G. Stavrakov, V. Valcheva, I. Philipova and I. Doytchinova, Eur. J. Med. Chem., 2013, 70, 372-379.

37 A. M. Montana, F. J. Bernal, L. Julia, F. Carlos, B. Consuelo, M. J. Prieto, M. Virtudes, F. X. Avilés, J. M. Mesas and A. María-Teresa, Bioorg. Med. Chem., 2008, 16, 1721-1737.

38 M. L. Circu and T. Y. Aw, Free Radicals Biol. Med., 2010, 48, 749-762.

39 M. Zhao, H. Ren, J. Chang, D. Zhang, Y. Yang, Y. He, C. Qi and H. Zhang, Eur. J. Med. Chem., 2016, 119, 183-196.

40 E. F. Abdelhaleem, M. K. Abdelhameid, A. E. Kassab and M. M. Kandeel, Eur. J. Med. Chem., 2017, 143, 1807-1825.

41 D. Yao, Y. Zhou, L. Zhu, L. Ouyang, J. Zhang, Y. Jiang, Y. Zhao, D. Sun, S. Yang and Y. Yu, Eur. J. Med. Chem., 2017, 140, 155-171. 